\title{
Petrology and Geochemistry of Peridotite Inclusions from the Mir kimberlite, Siberia
}

\author{
Roden, M.F.' ${ }^{1}$ Laz'ko, E.E. ${ }^{2}$ and Jagoutz, E. ${ }^{3}$
}

1. Department of Geology, University of Georgia, Athens GA 30602, U.S.A.

2. B.H.P., Moscow, Russia

3. Abteilung Kosmochemie, Max-Planck-Institut-fur-Chemie, Mainz, Germany

The Mir kimberlite of Siberia contains a diverse suite of mantle-derived xenoliths including coarse and sheared garnet lherzolites, eclogites, ilmenite-garnet wehrlites and a heterogeneous group of garnet pyroxenites. We have focussed on the mineral chemistry of a suite of lherzolites, wehrlites and pyroxenites (Table 1). All these rocks contain garnet with $\mathrm{CaO}$ contents indicative of saturation with diopside and are relatively $\mathrm{Mg}$-rich with the exception of the wehrlites. The latter rocks contain relatively $\mathrm{Fa}$-rich olivine $\left(\mathrm{FO}_{8485}\right)$ in contrast to the coarse and sheared lherzolites which contain Fo-rich olivines: $\mathrm{FO}_{91-93}$ and $\mathrm{FO}_{90-92}$ respectively. Only one garnet pyroxenite in the sample suite contains olivine, $\mathrm{Fo}_{94}$, but most other pyroxenites contain $\mathrm{Mg}$-rich pyroxenes (diopside $\mathrm{Mg}$ \# 89-96) and thus these rocks are mineralogically distinct from eclogites and similar to the coarse garnet lherzolites. The pyroxenites are typically coarse-grained and have relatively unstrained minerals. Most of these pyroxenites equilibrated within a pressure and temperature range (21-39 kb and $700-900^{\circ} \mathrm{C}$, after Brey and Kohler, 1990; Ellis and Green, 1979) similar to that estimated for the the coarse garnet lherzolites $\left(29-42 \mathrm{~kb}, 700-900^{\circ} \mathrm{C}\right)$ at $\mathrm{Mir}$, as well as the coarse garnet peridotites from another Siberian kimberlite, Udachnaya (Boyd et al., 1997). In contrast, the deformed or sheared garnet lherzolites equilibrated at much higher pressures and temperatures $\left(56-62 \mathrm{~kb}\right.$ and $\left.1170-1250^{\circ} \mathrm{C}\right)$. A similar dichotomy in equilibration conditions and texture exists for lherzolites from Udachnaya. Sheared ilmenite-garnet wehrlites from Mir also equilibrated at relatively high temperatures $\left(>1150^{\circ} \mathrm{C}\right.$ based on garnetclinopyroxene equilibria) and although the mineral assemblage is not sensitive to pressure, we infer that these deformed, high temperature wehrlites are probably derived from the same depths as the sheared lherzolites based on similar textures as well as the high calculated equilibration temperatures.

$\mathrm{Nd}$ isotopic data confirm the thermobarometric calculations: high temperature lherzolites have diopside and garnet which were in approximate isotopic equilibrium at the time of eruption whereas low temperature lherzolites and pyroxenites contain garnet and diopside which were not in equilibrium at the time of eruption.

The garnet pyroxenites are a particularly diverse group lithologically and include orthopyroxenites, websterites and clinopyroxenites. At least one pyroxenite contains garnet with exsolved diopside and in this sense is similar to the ultradeep inclusions (Haggerty and Sautter, 1990). However the garnet also contains exsolved rutile which appears to balance the excess $\mathrm{Si}$ contained in the exsolved diopside and no original majorite component in the garnet is required (Roden et al., ms.) . Moreover, isotopic disequilibrium between garnet and diopside, and thermobarometric calculations all suggest that this inclusion originated from within the lithosphere and no previous high pressure history is required. As a group the pyroxenites probably represent reequilibrated cumulates from intrusive magmas into the lithsophere.

The ilmenite-garnet wehrlites are a particularly fascinating lithology because their sheared 
textures and high temperatures of equilibration suggest an origin from the same source region as the sheared lherzolites. The ilmenite is $\mathrm{MgO}$-rich (Table 1 ) and has a peculiar texture characterized by elongate grains which occupy interstices between silicate grains as if the ilmenite records the texture of a melt with very low surface tension. Garnets are relatively $\mathrm{Ti}$-rich and $\mathrm{Cr}$ and $\mathrm{Mn}$ are zoned in the two examples we studied (Table 1). Tentatively we attribute the origin of these rocks to intrusion and metasomatism of continental lithosphere by an Fe-rich, Si-poor melt.

Table 1. Mineral Compositions

\begin{tabular}{|c|c|c|c|c|c|c|c|c|}
\hline \multirow{2}{*}{$\begin{array}{l}\text { Sample } \\
\text { Mineral }\end{array}$} & \multicolumn{4}{|c|}{ A239 - Coarse Gt Lherz } & \multicolumn{4}{|c|}{ TM-184 - Sheared Gt Lherz } \\
\hline & oliv & gt & $\operatorname{cpx}$ & opx & oliv & gt & cpx & opx \\
\hline $\mathrm{SiO}_{2}$ & 41.06 & 42.11 & 55.05 & 58.13 & 40.52 & 41.88 & 55.33 & 57.34 \\
\hline $\mathrm{TiO}_{2}$ & --- & 0.05 & 0.05 & 0.03 & --- & 0.86 & 0.45 & 0.21 \\
\hline $\mathrm{Al}_{2} \mathrm{O}_{3}$ & --- & 22.51 & 2.42 & 0.48 & --- & 20.16 & 2.62 & 0.74 \\
\hline $\mathrm{Cr}_{2} \mathrm{O}_{3}$ & --- & 1.56 & 1.21 & 0.12 & --- & 2.93 & 0.87 & 0.20 \\
\hline $\mathrm{CaO}$ & nd & 4.45 & 21.45 & 0.18 & 0.06 & 4.59 & 16.41 & 0.78 \\
\hline $\mathrm{MgO}$ & 50.99 & 20.18 & 16.11 & 36.21 & 48.77 & 20.42 & 17.41 & 34.08 \\
\hline $\mathrm{FeO}$ & 7.87 & 8.83 & 1.90 & 5.00 & 10.13 & 8.23 & 4.10 & 6.09 \\
\hline $\mathrm{MnO}$ & 0.09 & 0.28 & nd & 0.07 & 0.09 & 0.15 & 0.06 & 0.12 \\
\hline $\mathrm{NiO}$ & 0.32 & --- & --- & --- & 0.25 & --- & --- & --- \\
\hline $\mathrm{Na}_{2} \mathrm{O}$ & -- & nd & 1.84 & 0.03 & --- & nd & 2.41 & 0.24 \\
\hline Total & 100.33 & 99.97 & 100.03 & 100.25 & 99.86 & 99.22 & 99.66 & 99.80 \\
\hline
\end{tabular}

\begin{tabular}{|c|c|c|c|c|c|}
\hline Sample & \multicolumn{5}{|c|}{ TM-71 - Sheared Ilmenite-Garnet Wehrlite } \\
\hline Mineral & oliv & $\begin{array}{c}\text { gt } \\
\text { core }\end{array}$ & $\begin{array}{l}\text { gt } \\
\text { rim }\end{array}$ & $\operatorname{cpx}$ & ilm \\
\hline $\mathrm{SiO}_{2}$ & 41.05 & 41.15 & 41.38 & 54.73 & nd \\
\hline $\mathrm{TiO}_{2}$ & -- & 0.95 & 0.95 & 0.38 & 49.94 \\
\hline $\mathrm{Al}_{2} \mathrm{O}_{3}$ & $-\cdots$ & 19.29 & 20.05 & 2.41 & 0.64 \\
\hline $\mathrm{Cr}_{2} \mathrm{O}_{3}$ & --- & 2.77 & 1.59 & 0.57 & 0.86 \\
\hline $\mathrm{CaO}$ & 0.05 & 4.66 & 4.65 & 16.61 & nd \\
\hline $\mathrm{MgO}$ & 45.14 & 18.41 & 18.49 & 17.24 & 9.71 \\
\hline $\mathrm{FeO}$ & 14.49 & 11.99 & 11.88 & 5.69 & 40.74 \\
\hline $\mathrm{MnO}$ & 0.17 & 0.17 & 0.28 & 0.09 & 0.15 \\
\hline $\mathrm{NiO}$ & 0.13 & -- & --- & --- & 0.08 \\
\hline $\mathrm{Na}_{2} \mathrm{O}$ & -- & nd & nd & 2.30 & --- \\
\hline Total & 99.90 & 99.39 & 99.27 & 100.02 & 101.13 \\
\hline
\end{tabular}




\section{References}

Boyd, F.R., Pokhilenko, N.P., Pearson, D.G., Mertzman, S.A., Sobolev, N.V. and Finger, L.W., 1997, Composition of the Siberian cratonic mantle: evidence from Udachnaya peridotite xenoliths, Contr. Mineral. Petrol. 128, p. 228-246.

Brey, G. and Kohler, T, 1990, Geothermobarometry in four-phase lherzolites II. New thermobarometers, and practical assessment of existing thermobarometers: J. Petrol., 31, p. 13531378 .

Ellis, D.J. and Green, D.H, 1979, An experimental study of the effect of Ca upon garnetclinopyroxene Fe-Mg exchange equilibria: Contr. Miner. Petrol., 71, p. 13-22.

Haggerty, S.E. and Sautter, V, 1990, Ultradeep (greater than 300 kilometers), ultramafic upper mantle xenoliths, Science, 248, p. 993-996.

Roden, M.F., Jagoutz, E., Laz'ko, E.E. and Fleisher, C., ms., Some “ultradeep" kimberlite xenoliths are probably not derived from great depths, submitted to Nature. 